\title{
Hybrid numerical modelling of fluid and heat transport between the overpressured and gravitational flow systems of the Pannonian Basin
}

\author{
István Vass ${ }^{\mathrm{a}, \mathrm{b}, *}$, Tivadar M. Tóth ${ }^{\mathrm{b}}$, János Szanyi ${ }^{\mathrm{b}}$, Balázs Kovács ${ }^{\mathrm{c}}$ \\ a MOL Plc., Október huszonharmadika str. 18., 1117 Budapest, Hungary \\ ${ }^{\mathrm{b}}$ Department of Mineralogy, Geochemistry and Petrology, University of Szeged, Egyetem street 2., 6722 Szeged, Hungary \\ ${ }^{\mathrm{c}}$ Institute of Environmental Management, University of Miskolc, 3515 Miskolc-Egyetemváros, Hungary
}

\section{A R T I C L E I N F O}

\section{Keywords:}

Fractured reservoir

Overpressure

Geothermal energy

Numerical modelling

\begin{abstract}
A B S T R A C T
Fractured rock bodies are especially important in Hungary, where numerous hydrocarbon reservoirs and geothermal fields occur in the fractured crystalline basement of the Pannonian Basin. To simulate a 3D fracture network for both near well regions and at reservoir scale, a fractal geometry based DFN (discrete fracture network) modelling system (RepSim) was used.

To perform numerical simulation of the geological-hydrogeological problem, in which the hydraulic interaction is investigated between porous and fractured rock bodies, a finite element modelling system called FeFlow was applied. Modelling results suggest that the protruding basement highs govern heat transfer and fluid flow like a "hydro-geothermal chimney" owing to their stratigraphic and structural position as well as favourable hydraulic and thermal conductivities. Thus such fractured basement highs are deemed prospective for further geothermal investigations.
\end{abstract}

\section{Introduction}

Deep fractured reservoirs have been explored for geothermal energy production and hydrocarbons. Thermal springs attest to the viability of fractured reservoirs as potential sources of sustainable production of renewable geothermal energy. About $35 \%$ of the world's productive oil fields were discovered in naturally fractured carbonate reservoirs, while nearly half of the produced hydrocarbons are stored in such reservoirs (Nelson, 2001).

Geothermal systems are commonly grouped as conventional and non-conventional systems according to the heat conveyance mechanism. Conventional geothermal systems have a natural heat source, the reservoirs have high porosity and permeability, and natural groundwater flow systems convey the heat (Tóth, 2015). Non-conventional systems have a natural heat source but the reservoirs are either engineered and/or the fluids are artificially circulated.

Geothermal technology development has focused so far on extracting naturally heated steam or hot water from natural hydrothermal reservoirs. However, geothermal energy has the potential to make a more significant contribution on a global scale through the development of the advanced technologies, especially the exploiting of petrothermal resources using enhanced geothermal systems (EGS) techniques that would enable energy recovery from a much larger fraction of the accessible thermal energy in the Earth's crust. In the IEA geothermal roadmap vision 2011, geothermal energy is projected to provide 1400 TWh annually for global electricity consumption by 2050 (IEA, 2011).

The existing term 'enhanced or engineered geothermal system' (EGS) has its roots from the early 1970's when a team from Los Alamos National Laboratories began the hot dry rock (HDR) project at Fenton Hill, USA (Cummings and Morris, 1979). HDR was also known as hot fractured rock because of either the need to fracture the virtually impermeable formations or the presence of natural fractures in the hot reservoir (Breede et al., 2013). The Massachusetts Institute of Technology defines EGS as "engineered reservoirs that have been created to extract economical amounts of heat from low permeability and/or porosity geothermal resources. EGS would exclude high-grade hydrothermal but include conduction dominated, low permeability resources in sedimentary and basement formations, as well as low grade, unproductive hydrothermal resources" (Tester et al., 2006). According to Potter et al. (1974), the most suitable rock types for EGS are granite or other crystalline basement rocks at depths of 5-6 km. Most hydraulic fracturing projects, aiming to create an EGS, target granitoids, because of their favourable petrophysical properties (virtually no porosity and permeability; high thermal conductivity) and their geological settings below $>5 \mathrm{kms}$ where sufficient heat is available for power production purposes (Rybach, 2010).

\footnotetext{
* Corresponding author.

E-mail addresses: ivass.geo@gmail.com (I. Vass), mtoth@geo.u-szeged.hu (T.M. Tóth), szanyi@iif.u-szeged.hu (J. Szanyi), kovacs.balazs@gama-geo.hu (B. Kovács).
} 
In the Pannonian Basin, regional gravitational flow system is located below the Hungarian Great Plain which is separated by sedimentary layers from the fluid system stored in the deep, overpressured, fractured crystalline and carbonate basement regime (Stevanovic et al., 2015; Horváth et al., 2015). The basement complex is not impermeable in spite of its great depth and fluids of various age and content are stored in there due to the secondary porosity and permeability. The overpressure has generally been maintained and the flow system has been separated from the overlaying hydrostatic regime where thick quasiimpermeable covering sediments were deposited. However the hydraulic connection could be developed between the two zones (Tóth and Almási, 2001; Varsányi and Kovács, 2009; Mádlné Szőnyi et al., 2005) in such not uncommon geological-hydrogeological situations where the insulating sedimentary layers are extenuating or missing due to the basement morphology. The presence of the saline water with high total dissolved solid content in the deeper overpressured system has been detected in the Pannonian and Pleistocene layers by geochemical methods at several locations. These areas could have significant importance for hydrocarbon and geothermal energy exploration (Pogácsás et al., 1994; Dövényi et al., 2005). As there is only very limited information about the hydrodynamic interplay between the two different reservoir regimes, numerical flow and heat transport modelling together with fracture network modelling would serve an effective tool to obtain more information and help understanding such a geological-hydrogeological system.

The main objective of this paper is to analyse the feasibility of hydraulic and thus hydrothermal communication between the overpressured deep basin zones and the shallow normal pressured flow system through the fracture network of the metamorphic highs. Furthermore, we discuss how this hydrodynamic situation can modify the potential field inside and above these crystalline highs, and which direction the basement fluids get supply from, which flow paths can be realistic. The second part of the investigation is to model the rate of anomaly caused by conductive and convective heat flow in the temperature field of the basement metamorphic domes.

\section{Geological setting}

Due to its complex tectonic evolution during the Neogene (for details see e.g. Tari et al., 1992; Albu and Pápa, 1992; Lórincz, 1996; Csontos and Nagymarosi, 1999; Tari et al., 1998), the Pannonian Basin is at present a mosaic of deep sub-basins and uplifted basement highs. Although, these crystalline domes are in many details different concerning their metamorphic and structural evolution, most of them consist essentially of diverse gneiss and amphibolite type rocks (Tóth and Schubert, 2000). Following the post-Variscan uplift of the metamorphic terrain under unknown circumstances and the widespread nappe tectonics during the Cretaceous (Tari et al., 1998), the most important brittle events of the basement belong to the subsidence of the Pannonian Basin in the Neogene. This episode coincided with a multiphase tectonic evolution with subsequent compressive, extensive and strike-slip events (Tari, 1994; Bada and Horváth, 1998).

The Szeghalom High (Fig. 1) is one of the most investigated among the basement highs in the Villány-Bihor and Békés-Codru tectonic units, therefore it was used as a standard according to the geological structure.

The basement consists of intermediate and high grade metamorphic rocks, primarily of amphibolite and gneiss, and secondarily of mica schist. The boundaries of the rock blocks, characterized by different metamorphic evolutions, are delineated by post-metamorphic strikeslip zones (Tóth and Redlerné Tátrai, 2008); the basement high is divided into several smaller units by normal faults of approximately NW strike orientation. A detailed study of fracture filling mineral phases infers formation during decreasing temperature that probably was governed by basement exhumation (Juhász et al., 2002). Terrestrial pollens enclosed in vein filling calcite crystals infer that fracture network formed in the Middle Miocene Badenian age (Tóth et al., 2003). Fracture filling quartz crystals contain tiny HC-bearing fluid inclusions, which are of different chemical compositions even in case of a single high (Schubert and Tóth, 2003; Schubert et al., 2007). These data suggest that at the time of migration of the ancient oil into the basement, several separated fluid regimes co-existed in the fractured metamorphic realm. Pap et al. (1992) report a similar situation about a recent well, from which fluids of different compositions are produced at different depths. These and numerous similar data imply that the fractured rock mass of the metamorphic basement does not form a single conductive network; it possibly breaks down into several independent percolation clusters.

The sedimentary cover of basement rocks also differs in the high and basin areas significantly. In the sub-basins sandy and pebbly sediments occur, which are covered by a thick layer (at places even $200 \mathrm{~m}$ ) of impermeable lacustrine marl. Above the uplifted crystalline domes these marls usually are missing and a fine to coarse grained sandstone follows instead.

Hydrodynamically, the Pannonian Basin can be subdivided into an upper and a lower regime (Almási, 2001; Tóth and Almási, 2001; Szanyi and Kovács, 2010). The upper one is a gravity driven system (Erdélyi, 1976), while overpressured zone was developed in the lower regime essentially due to tectonic compression (Almási, 2001; Tóth and Almási, 2001). Vertical compaction and aquathermal pressuring were also attributed to the origin of overpressure according to earlier interpretations (Somfai, 1970; Szalay, 1982, 1983). Another theory assigns lateral tectonic compression as an indirect cause to explain vertical compaction (Horváth, 1995; Horváth et al., 2015; Van Balen and Cloetingh, 1994). The reservoir of the upper regime consists of shallow marine and delta facies sediments (Bérczi, 1988) with good porosity and permeability. On the contrary, the lacustrine clays and marls of the lower zone can isolate pressure resulting in an overpressure of even 15-20 MPa within a 100-200 m depth interval (Almási, 2001). The overpressure can also be detected in the fractured metamorphic basement. It is wellknown that inside the sedimentary basin the overpressured regime is in hydraulic connection with the upper zone through high permeability fault zones (Tóth and Almási 2001; Almási, 2001). A question arises whether those uplifted metamorphic domes, which are not covered by the very low permeability clay - clayey marl layers, may play the same role in the hydraulic system of the Pannonian Basin.

The average geothermal gradient in the Pannonian Basin is $\sim 50{ }^{\circ} \mathrm{C}$ / $\mathrm{km}$ (Dövényi et al., 1983). The mean annual temperature at the surface is $\sim 11^{\circ} \mathrm{C}$ giving $\sim 60^{\circ} \mathrm{C}$ and $\sim 110^{\circ} \mathrm{C}$ as a typical rock and water temperature at 1 and $2 \mathrm{~km}$ depths (Dövényi and Horváth, 1988). The main reason for such an uncommon behaviour is that beneath the Pannonian Basin the crust is only $\sim 25 \mathrm{~km}$ thick. As a consequence, the heat flux is high $\left(\sim 90.4 \mathrm{~mW} / \mathrm{m}^{2}\right)$ (Dövényi and Horváth, 1988). In addition, crystalline rocks usually have better heat conductivity than porous sedimentary sequences resulting in anomalously high temperatures inside the metamorphic domes (e.g. there is $290^{\circ} \mathrm{C}$ at a depth of $4800 \mathrm{~m}$ inside a gneiss dome, while in the neighbouring sedimentary basin $250{ }^{\circ} \mathrm{C}$ is typical at a depth of $5200 \mathrm{~m}$, Posgay et al., 2006). All these parameters make the whole region rather promising for diverse geothermal utilizations.

\section{Methods}

The fracture network of the basement rocks has a key role as both concerning fluid migration and storage capacity and it was studied in details for many cases. To simulate 3D fracture network for both near well regions and at reservoir scale, a fractal geometry based DFN (discrete fracture network) modelling system was used. For modelling we measured the most essential geometric parameters of the fractures (length distribution, orientation, spatial distribution of fracture seeds, length-aperture relationship) using selected rock specimens and CT images (Tóth et al., 2004). 


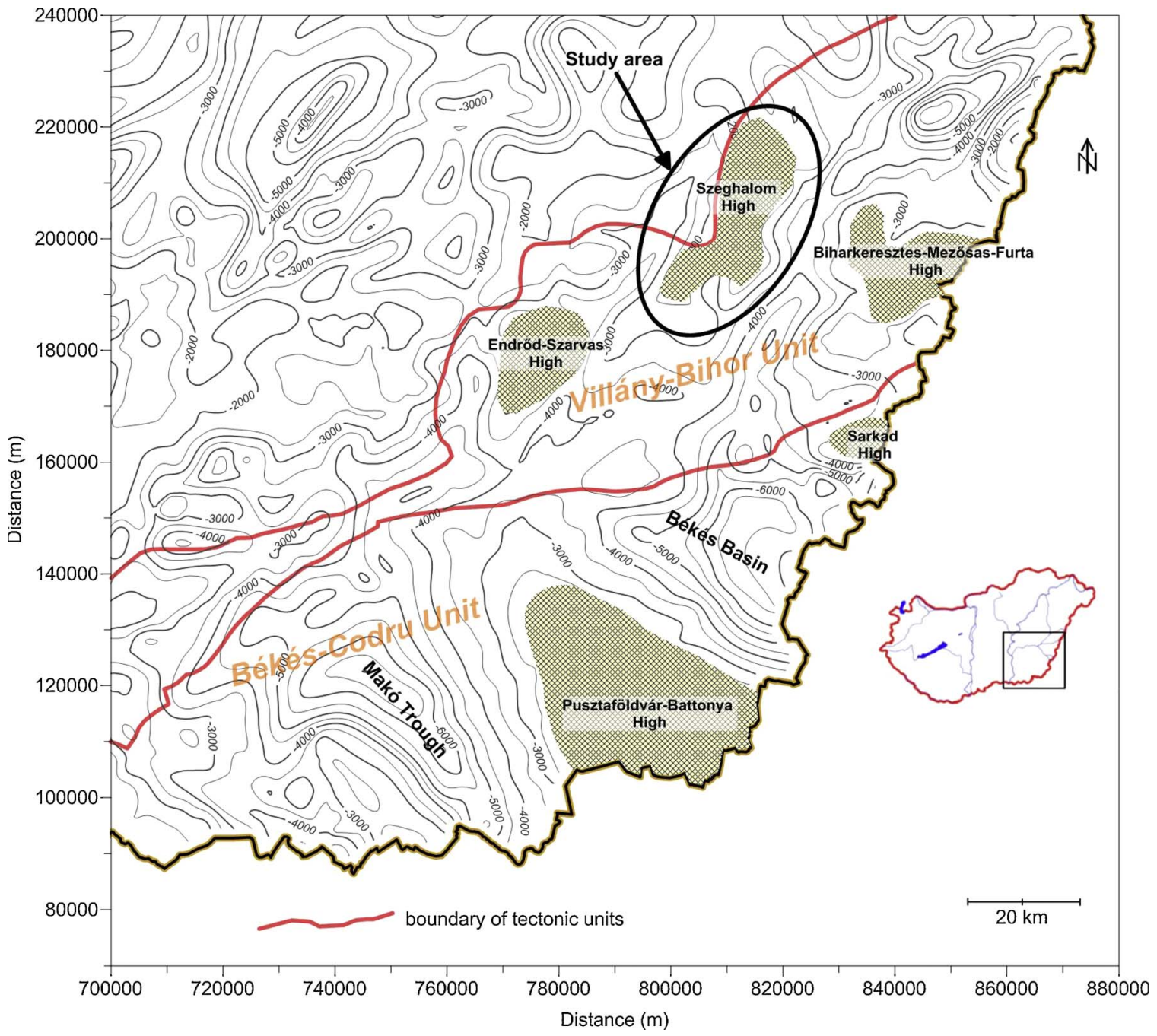

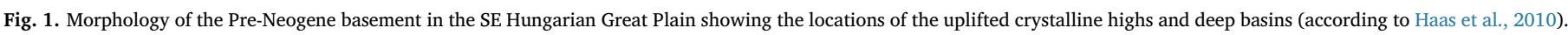

Fracture networks can be described using fractal geometry in two respects. On one hand, length $(L)$ distribution follows the power law distribution $\left(\mathrm{N}(L)=F \cdot L^{E}\right)$; while on the other hand, fractures above any length threshold display a scale invariant pattern in 3D (Barton and Larsen, 1985; La Pointe, 1988; Tsuchiya and Nakatsuka, 1995). Since fracture aperture is only related to the hydraulic conductivity and does not influence the network geometry, aperture is calculated for each fracture assuming a linear function between length and aperture (Vermilye and Scholz, 1995; Gudmundsson, 2000; Gudmundsson et al., 2001). The discrete fracture network modelling system, called RepSim (Tóth et al., 2004) is based on these assumptions, and follows the next steps.

1) The model region is subdivided into unit cubes of the homogenous parameter set. Each cell is characterized by fractal dimension of the fracture seeds $(D)$, parameters of the fracture length distribution function $(E, F)$, a set of dip and strike $(\alpha, \beta)$ data pairs as well as an $A$ constant for calculating the length-aperture function. These cubes appear as the generator elements of the following recursive algorithm.

2) Next, edges of the boxes are divided into $r(\in \mathrm{N})$, so that there form $r^{3}$ new cubes.

3) From this set of smaller cubes, using the input fractal dimension and based on the relation $\mathrm{N}(r)=r^{-D}$, the number of boxes of edge length $r$ that contain fracture seed can be calculated. The filled boxes themselves are selected at random afterwards.
4) Division and selection of new sets of smaller cubes are repeated in a recursive manner; while, in the final step, the centre points of the last set of cubes are chosen as seed points. As the boxes become smaller, the number of filled boxes increases.

Because of the recursive nature of the algorithm and the use of the resolved box dimension, the final aggregate of points is a fractal of the same measure $(D)$. The points are finally used as seeds for penny-shaped fractures with random diameter, strike and dip values of the measured distributions. Using the simulated 3D fracture network, the essential hydrodynamic parameters as fractured porosity, elements of the $3 \times 3$ permeability tensor, sizes and spatial positions of communicating fracture sub-systems and REV (representative elementary volume) were computed.

Fracture porosity can be described as the ratio of the volume of flat disks representing discrete fractures to the volume of the embedding block, where the volume occupied by fractures can be determined by a finite integral of the blocks containing disks at a given volume. The calculated porosity values usually follow normal distribution, so the mean value $(\mathrm{M})$ and standard deviation $(\sigma)$ are ideal for characterizing porosity. As the calculated $\mathrm{M}$ and $\sigma$ tend to display a large-scale variation for different parameter inputs, the variation coefficient $(\gamma=\sigma$ / $\mathrm{M}$ ) is applied in order to calculate REV for the individual cases (Tóth and Vass, 2011). Permeability tensor is also calculated by the intrinsic algorithm of RepSim. This works on the basis of cubic law describing the laminar flow in a parallel plate model (Witherspoon et al., 1980) 
then elements of the permeability tensor are derived following the approach suggested by Oda (1985).

The analysis of hydrodynamic and heat transport processes of such hydrogeological systems disclosed in the introduction is considerably difficult with common methods, as software packages written for numerical flow modelling in porous media are not able to properly handle the structural elements typical for fractured reservoirs. Giving the solution, a complex fracture network analysis method and modelling procedure were used that provide tool for those problems which try to find solution for fluid flow properties of reservoirs built up by mainly crystalline rocks.

The essence of the method is that the information obtained from the fractured rock is being systematically built into the structure of the numerical flow and transport model. First the most important parameters (fracture density, fracture length and aperture distribution, orientation) of the individual fractures and the whole network of the rock mass are being set in an appropriate discrete fracture network simulator. The next step is to make further hydrodynamic parameter calculations on the stochastically generated fracture networks and compute percolation and representative elementary volume data. This information will be presented in an equivalent continuum model as the input parameters of the hydrodynamic and heat transport calculations. Actually, considering the whole procedure, a hybrid type modelling is performed with the connection of the discrete fractures and the homogenized flow field.

The importation of integrated fracture parameters (REV - cell size, connected fracture groups - effective porosity, permeability tensor hydraulic conductivity) and porous rock parameters into the finite element numerical modelling systems (Diersch, 2002) is performed by common methods.

\section{Results and discussion}

\subsection{Fracture network properties}

For fracture network modelling only the most frequent lithologies, gneiss and amphibolite were considered. Both rock types are available in the form of core samples from several HC wells penetrated the basement in the Szeghalom field, so the most important geometric parameters could have been measured directly in laboratory (Tóth et al., 2004).

Length distributions in each studied case can be approximated by a power law distribution so that linear regression is calculated between $\log _{2} N(L)$ and $\log _{2} L$ data with a very tight correlation coefficient $(r>0.95)$. While long fractures are characteristic for amphibolite, regression lines are significantly steeper for the gneiss samples suggesting a bias towards short fractures. Representative fracture length exponents (E) for the two rock types are $\sim-1.8$ (amphibolite) and $\sim-2.5$ (gneiss), respectively. Additionally, concerning spatial density, amphibolite can be characterized by a rather dense fracture network ( $D$ for fracture seeds is $\sim 1.3$ ), while the same parameter for gneiss $(0.9)$ suggests a system of more sporadic fractures (Tóth and Vass, 2011). The spatial orientation show $\sim 60^{\circ}$ dipping angle between the most characteristic fracture sets in case of both lithologies.

The simulation results shed light on the fundamentally different hydraulic behaviours of the two, amphibolite and gneiss lithological units. Essentially no percolation cluster develops in the gneiss domain; ten independent runs suggest that the maximal sizes of the communicating fracture sets do not exceed $1-2 \%$ of the whole number of fractures. In the case of a homogenous amphibolite body, the largest net of fractures involves around $70-80 \%$ of the whole fracture network (Fig. 2).

In such a mature network, several substitute pathways exist even if some fractures are mineralised and so cannot take part in communication. There are significant differences in all hydrodynamic parameters comparing the two basic crystalline lithologies. REV size is
$20 \mathrm{~m}$ for amphibolite and $\sim 70 \mathrm{~m}$ for gneiss; effective porosity is $\sim 2 \%$ and $\sim 0.2 \%$, permeability is $1.1 \cdot 10^{-17} \mathrm{~m}^{2}$ and $8.4 \cdot 10^{-20} \mathrm{~m}^{2}$ with anisotropy of around 1.2.

\subsection{Water and heat flow}

Although the flow model was built following the topography and stratigraphy of a certain metamorphic dome (Szeghalom High, Fig. 1), the ambition of modelling using the FeFlow code was to understand filling mechanism of the metamorphic reservoirs of the Pannonian Basin in general. For this reason a $10 \times 12 \mathrm{~km}^{2}$ large, $1500 \mathrm{~m}$ deep model was built with the bottom layer at $2750 \mathrm{~m}$ below the present surface.

Geology follows the common situation: the basement dome consists of amphibolite and gneiss; the two metamorphic rock types with hydraulically different parameters were located randomly inside the crystalline body, because there is no information about their actual spatial distribution. It is covered by pebbly sediments in the deep basins and thick, lacustrine clayey marl afterwards but the centre high of the crystalline rocks is not covered with the latter impermeable formations. The top of the section consists of sandstone throughout the model block (Fig. 3).

For modelling, the above structure was divided into 30 layers including 14300 grid points in each slice. The thickness of the layers is uniformly $50 \mathrm{~m}$ through the whole vertical profile. For the fractured rock body, grid point distance is defined based on the typical REV sizes discussed above. The hydrodynamic parameters represent well-log data from the study area (Table 1., Fig. 3).

In the cases of the sandstone and conglomerate formations, porosity and transmissivity data decrease downwards; $\mathrm{Kh}$ and $\mathrm{Kv}$ data decrease also horizontally away from the top of the metamorphic basement. The parameters calculated based on the RepSim model for the fractured metamorphic rocks were corrected with depth following the approach of Morrow et al. (1994). The initial hydraulic heads were calculated based on the appropriate $\mathrm{p}(\mathrm{z})$ profiles; the typical hydraulic gradients are $\sim 10 \mathrm{MPa} / \mathrm{km}$ above the marl horizon, vary around $\sim 23 \mathrm{MPa} / \mathrm{km}$ below the marl bottom, while the pressure transition between the two zones is considered to be continuous (Fig. 4). The upper boundary was defined by constant hydrostatic head. The lateral inflow from the sides into the sediments deposited on the slope of the crystalline high is allowed by fix head cells. The lower hydraulic boundary was also set to be constant (but overpressured) through which fluid inflow is possible from the deep metamorphic reservoirs due to the compressive tectonic regime (Tóth and Almási, 2001). Due to boundary conditions and hydraulic parameters the upper part of model represents the gravity driven flow system while the lower part represents the overpressured system (Fig. 4.).

To set up the initial heat transport parameters for the model, $50{ }^{\circ} \mathrm{C}$ / $\mathrm{km}$ geothermal gradient was used based on the average value of temperature logs taken in $\mathrm{HC}$ wells which penetrated the crystalline basement. The upper and side boundaries, where lateral inflow is allowed, are characterized by constant temperature. In the case of thermal conductivities (Table 2) we used the measurement results taken on core samples then temperature correction was also applied for these values (Chapman et al., 1984).

Constant heat flow was set to $111.4 \mathrm{~mW} / \mathrm{m}^{2}$ at the bottom of the model. This is based on the following assumptions: lateral change of the lithology can be neglected at deeper horizons and the heat flow from the mantle is uniform within our bounded area.

Under these circumstances the simulation approaches a quasi-stationary situation aside from the temporal change of the stress field, where the overpressure can be compensated through the fractured basement reservoir as controlled by the defined boundary conditions. The equipotential lines remain dense and parallel in the clayey marl aquitard, where the pressure cannot be compensated in spite of the high hydraulic gradient due to low hydraulic conductivities (Fig. 5). 


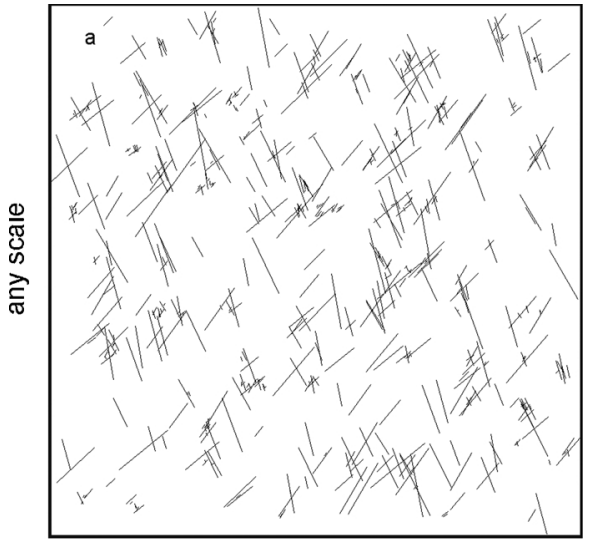

any scale

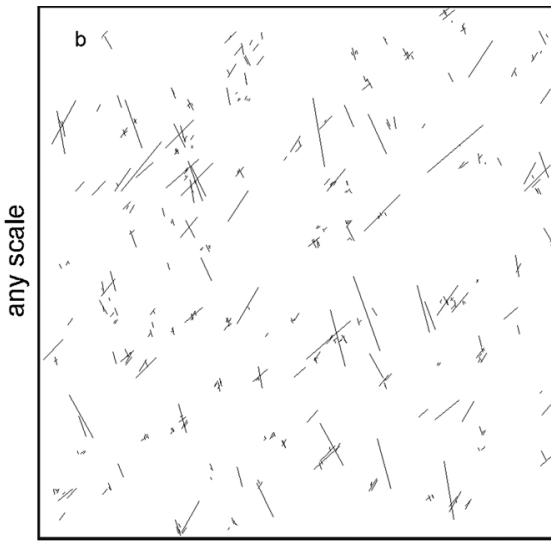

any scale
Fig. 2. Vertical sections of typical 3D fracture network models generated for a) amphibolite, b) gneiss.

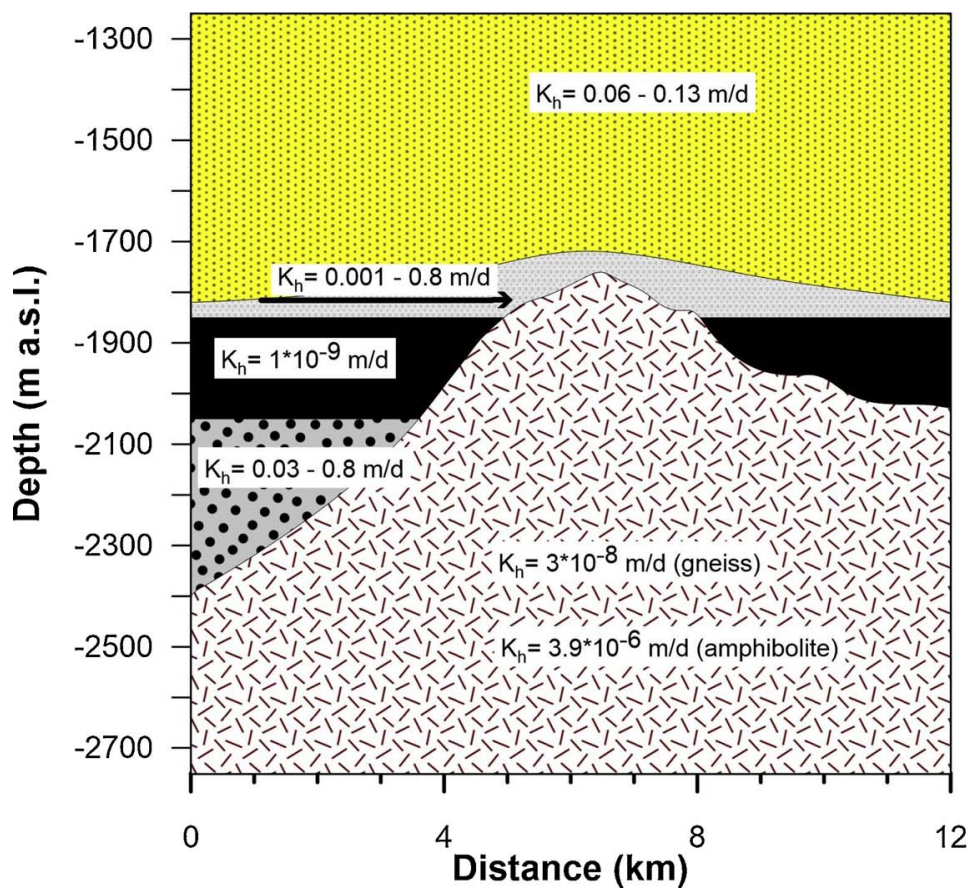

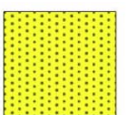

Sandstone

(Szolnok Formation)

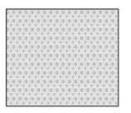

Abrasional conglomerate and breccia

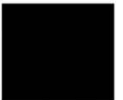

Marl, clayey marl (Endrőd Formation)

$\because \because \because \because \quad$ Conglomerate (Békés Formation)

Fractured metamorphic Basement (pre-neogene)

Fig. 3. Schematic geological cross-section of the Szeghalom High with hydraulic conductivity $\left(\mathrm{K}_{\mathrm{h}}\right)$ data.

Significant depression develops inside the fractured rock body (Fig. 6), which still remains overpressured considering the pressure gradient of the upper sediments. Below the impermeable clay - the recharge is continuous in the lower region due to the tectonic compression of the deeper overpressured regime, however locally negative pressure anomalies can be expected at the bottom of Neogene clastic sediments. Accordingly the fluid penetrates the basement fracture network from the coarse grain sediments deposited on the slope of the crystalline complex (Vass et al., 2009) despite the low permeability of the amphibolite and gneiss rocks. It is in accordance with the flow characteristics of most hydrocarbon fields that fluid flow directions are found to the basement highs from mature source rocks in deeper troughs in the Pannonian basin on the local scale (Spencer et al., 1994; Horváth et al., 2015).

The flow velocity increases suddenly according to the high flux and a relatively quick upflow takes effect inside the "chimney" (Fig. 7). The fluid flows towards the centre of the crystalline dome from the model sides then turns upwards within the chimney. The flow velocity is getting higher and reaching its maximum at the top of the crystalline core.

Table 1

Most important rock hydrodynamic parameters applied in numerical model.

\begin{tabular}{|c|c|c|c|c|c|}
\hline Depth (m below surface) & Rock type & & Porosity (\%) & Kh (m/day) & $\mathrm{Kv}$ (m/day) \\
\hline $1250-1750$ & Turbiditic fine grained sandstone & & $25-26$ & $0.06-0.13$ & $0.03-0.06$ \\
\hline $1750-1850$ & Sandstone, abrasional conglomerate and breccia & & 25 & $10^{-3}-0.8$ & $5^{*} 10^{-4}-0.4$ \\
\hline $1850-2050$ & Lacustrine clay, clayey marl & & 5 & $10^{-9}$ & $5 * 10^{-10}$ \\
\hline $2050-2650$ & Basal conglomerate & & $12-21$ & $0.03-0.8$ & $0.005-0.15$ \\
\hline \multirow[t]{2}{*}{$1800-2750$} & Metamorphic rocks & Amphibolite & 2 & $3.9 * 10^{-6}$ & $3.7 * 10^{-6}$ \\
\hline & & Gneiss & 0.2 & $3 * 10^{-8}$ & $2.8 * 10^{-8}$ \\
\hline
\end{tabular}




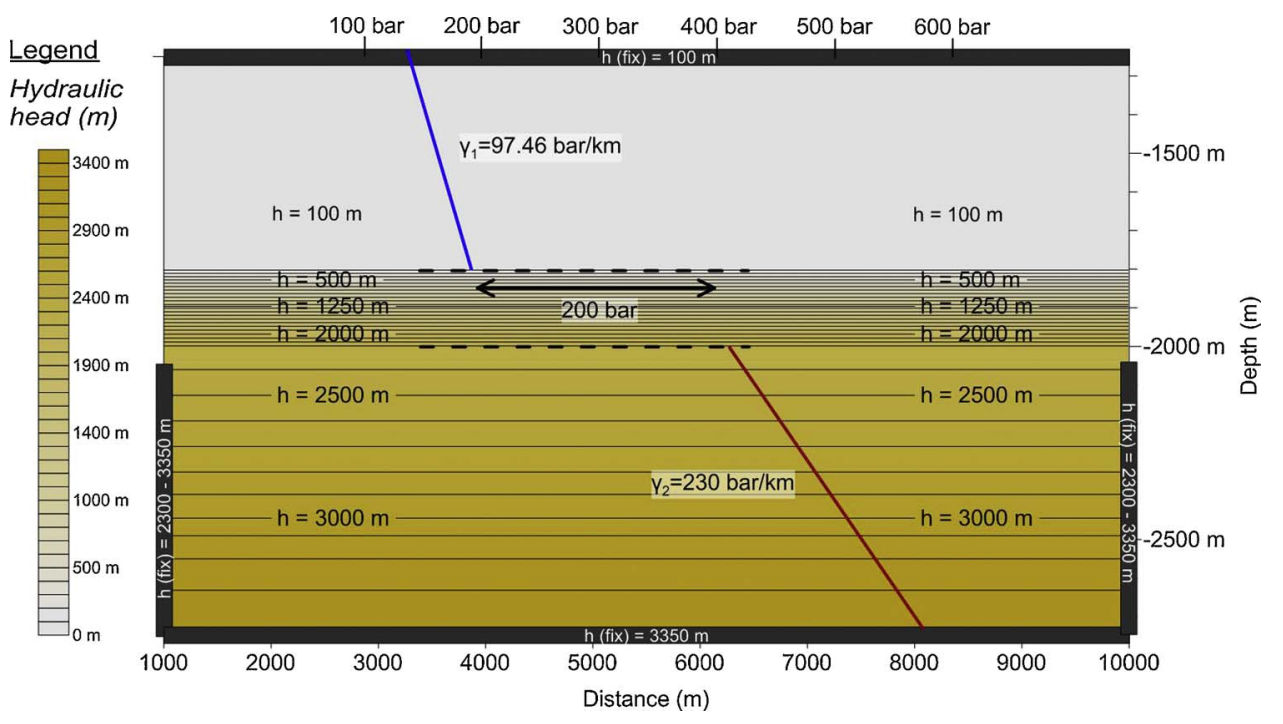

Fig. 4. Vertical cross section of the model with initial hydraulic head distribution and boundary conditions.

Table 2

Characteristic thermal conductivity values of different lithologies applied in the model.

\begin{tabular}{lll}
\hline Lithology & $\begin{array}{l}\text { Average thermal } \\
\text { conductivity }(\lambda)\end{array}$ & $\begin{array}{l}\text { Average thermal } \\
\text { conductivity corrected by } \\
\text { temperature effect }(\lambda)\end{array}$ \\
\hline Szolnok sandstone & 2.20 & 1.78 \\
Abrasional conglomerate & 2.80 & 2.18 \\
$\quad$ and breccia & & \\
Endrőd Formation & 1.97 & 1.50 \\
Békés conglomerate & 2.80 & 2.03 \\
Gneiss & 3.44 & 2.92 \\
Amphibolite & 2.91 & 2.47
\end{tabular}

The hydrodynamic model confirms the geochemically proved phenomena that deep fluids join to and mix with the lower salinity, younger $\mathrm{HCO}_{3}$ rich water of the gravitational flow system. The brine arriving from below the regional discharge areas of the UpperPannonian and Pleistocene flows directly upwards, while fluids come from below recharge areas are diverted laterally before flowing up to the surface (Varsányi and Ó. Kovács, 2009; Mádlné Szőnyi et al., 2005; Mádl-Szőnyi and Tóth, 2009).

The heat transport results suggest extra heat in the middle region of the model. This positive temperature anomaly is caused by the higher thermal conductivity of the metamorphic rock material (conductive transport) and, on the other hand, heat is also transported by the upflowing hot fluid (convective transport) at the top of the dome. The temperature anomaly is around plus $20^{\circ} \mathrm{C}$ that slightly decreases horizontally between the model's edges and middle axis and decreases vertically as well as moving shallower (Fig. 8). The maximum difference is presented in the centre of the chimney (Fig. 9).

The role of the conductive heat transfer was estimated analytically by calculating the Peclét-number. The value of $\sim 0.8$ refers to that convection should be also considered $\left(P_{e}>0.5\right)$ in the process of heat transfer but not as the main driving force $\left(P_{e}>1\right)$. Accordingly the components of conduction and convection mean approximately $10-10{ }^{\circ} \mathrm{C}$ positive temperature difference at the top of the overpressured basement high (Vass, 2013). It should be noted that low permeability can cause reduced effect of convective heat transfer in several areas in the Pannonian Basin. This positive anomaly is slightly preserved in the shallower sediments above the centre of the fractured basement high (Fig. 8) making these areas prospective for geothermal energy. This effect becomes to be neglected a few hundred meters above the basement. Depending on the absolute depths, temperature and permeability of the fractured basement top, EGS or even hydrothermal systems can be viable in several regions of the Pannonian Basin.

\section{Conclusions}

A generalized model has been presented to analyse hydrodynamic

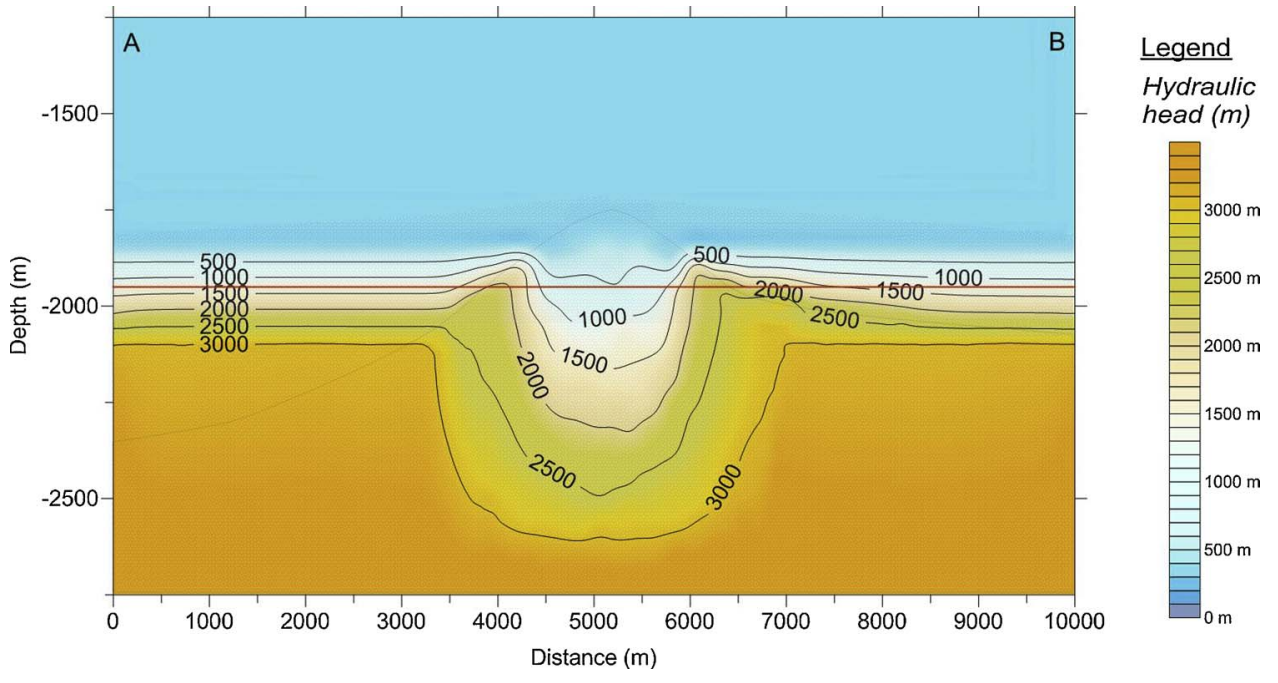

Fig. 5. Hydraulic head distribution (m) in Szeghalom High on a vertical cross section through the model centre (its position is indicated on Fig. 6 by red line between $\mathrm{A}$ and $\mathrm{B}$ ). (For interpretation of the references to colour in this figure legend, the reader is referred to the web version of this article.) 

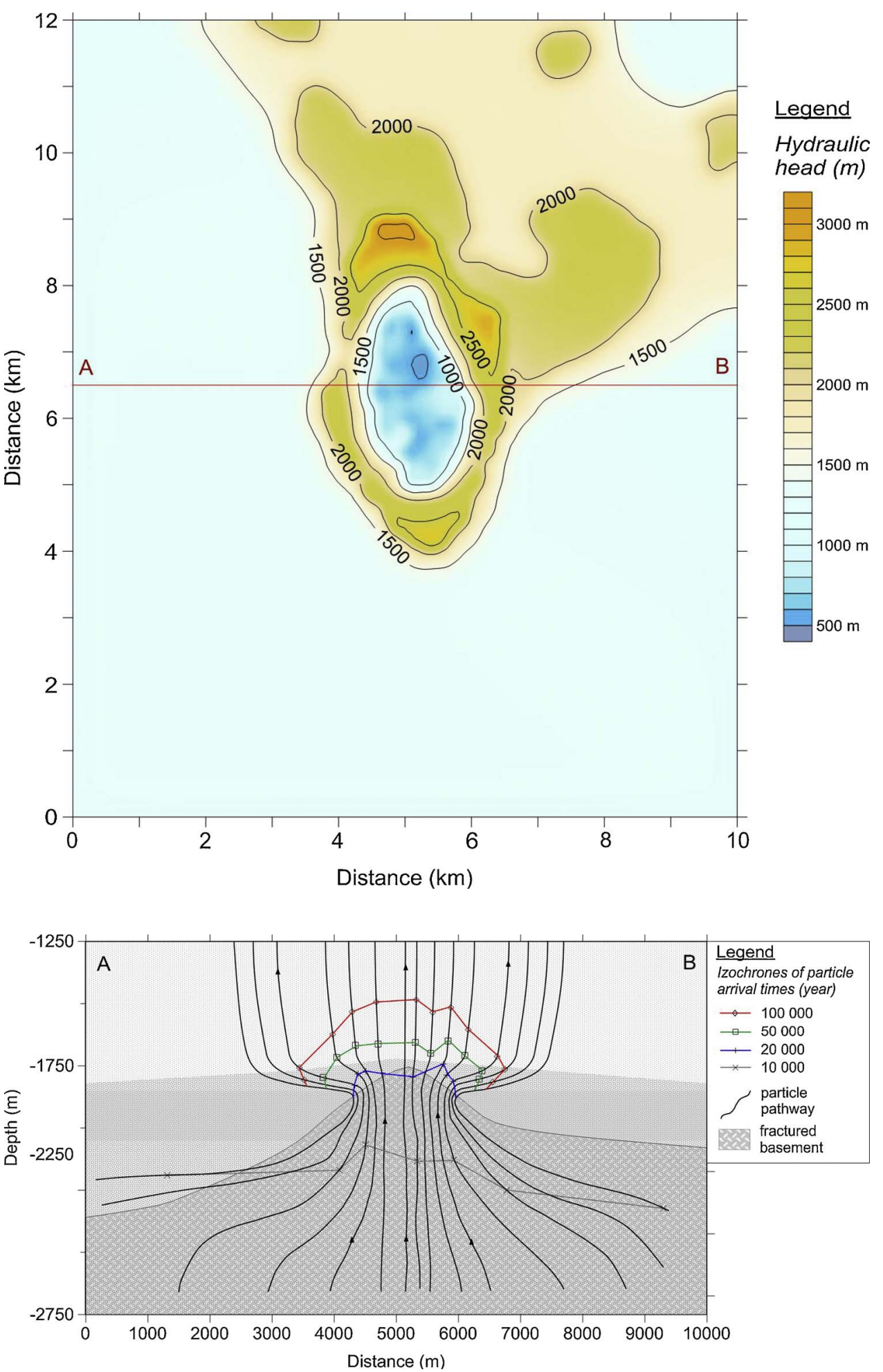

Fig. 6. Hydraulic head distribution (m) in Szeghalom High on a horizontal cross section at the top of the basement high (its vertical position is indicated on Fig. 5 by red line). (For interpretation of the references to colour in this figure legend, the reader is referred to the web version of this article.)
Fig. 7. Pathways and tracking times of fluid particles starting from the bottom of the fractured metamorphic dome - discharge area. interaction between the deep, overpressured sedimentary basins, the uplifted, fractured metamorphic highs and the shallow, gravity driven flow systems of the Pannonian Basin. We could show that the most abundant rock type of the crystalline basement, gneiss, has no communicating fracture system, while amphibolite is well above the percolation threshold. Consequently, due to its complex lithology and structural evolution, the basement has a compartmentalized flow system.

It has long been known that because of regional geological reasons, water regime is highly overpressured in the deepest sedimentary sub- basins. Our model suggests that even if the permeability of the metamorphic rocks is low, such a geological situation makes possible that fluids can penetrate the fractured basement and migrate upwards through the metamorphic chimneys. Results of the model also suggest that under the given geological circumstances, regions of the metamorphic highs of the Pannonian Basin are rather prospective for using geothermal energy: conductive and convective heat transfer has almost equal effects in generating approximately $20^{\circ} \mathrm{C}$ total positive temperature anomaly at the top of the basement highs. The effect of this extra heat can be observed through a few hundred meters above the 


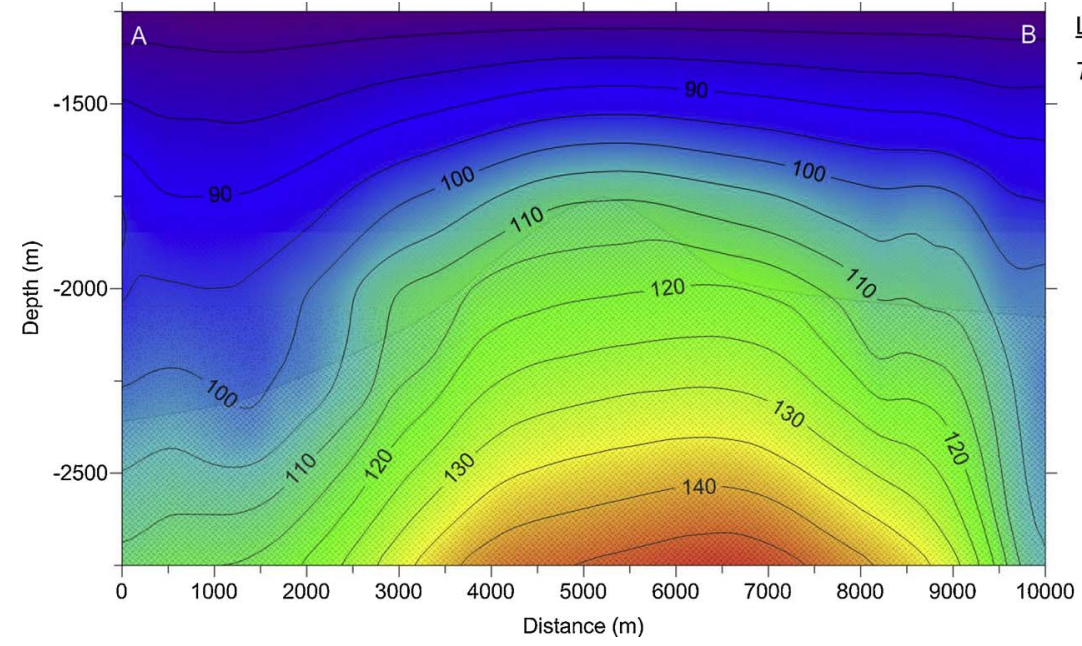

Legend

Temperature $\left({ }^{\circ} \mathrm{C}\right)$

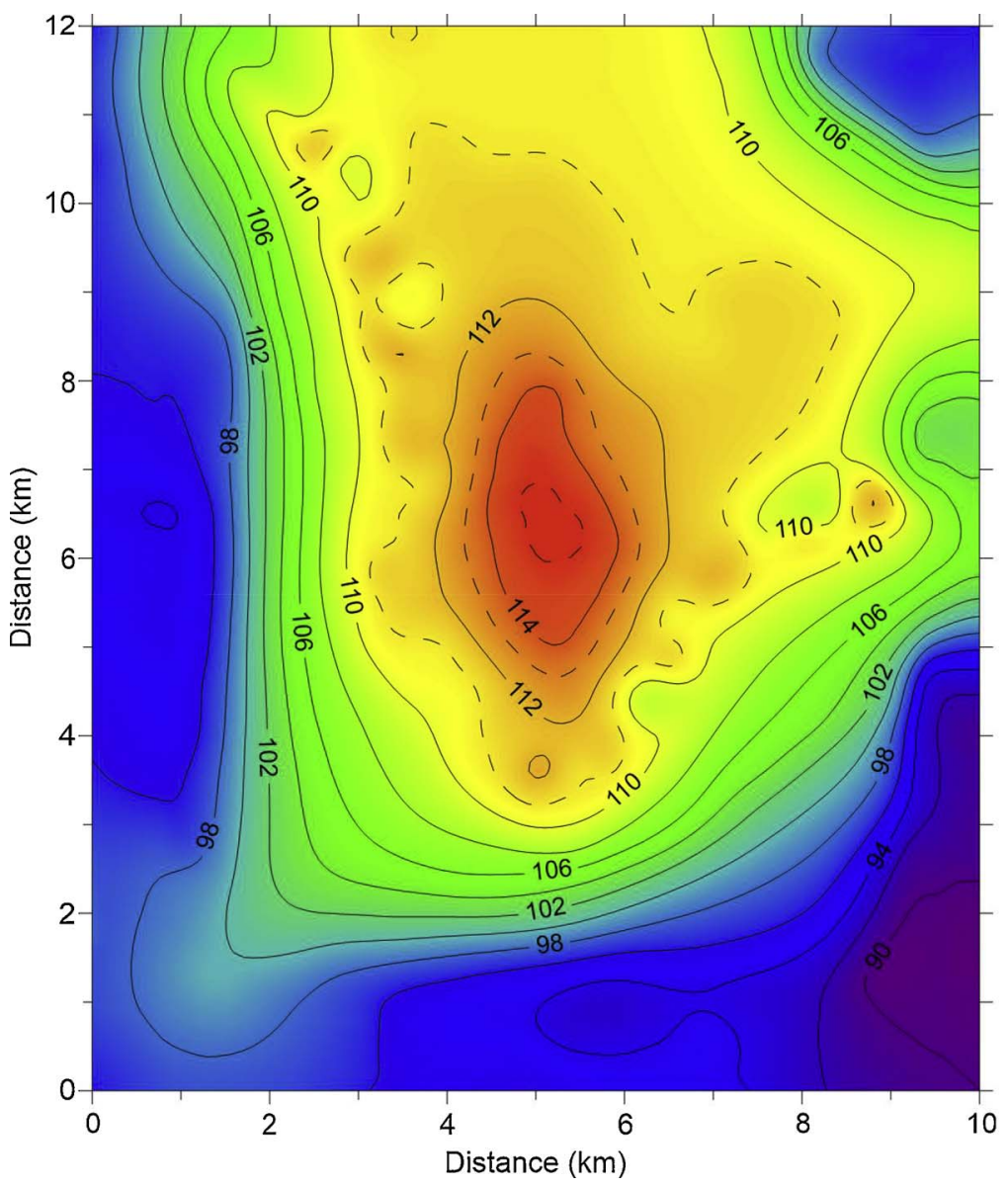

\section{Legend}

\section{Temperature $\left({ }^{\circ} \mathrm{C}\right)$}

112

108

104

100

96

92

88

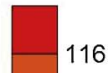

Fig. 8. Temperature field calculated in the basement high and overlaying sediments.
Fig. 9. Temperature distribution on a horizontal cross section at the top of the basement high. basement highs.

It is evident that a fractured rock volume of favoured geometry coupled with a positive temperature anomaly will have positive effects on the produced temperatures and available flow rates. Geothermal production wells can be drilled into such regions around the sides of Makó Trough and Békés Basin (e.g. Szeghalom High, PusztaföldvárBattonya High, Endrőd-Szarvas and Biharkeresztes-Mezősas-Furta Highs, Fig. 1) either targeting the basement or the insulating sediments, while injection wells have better conditions a bit far from the centre of fractured domes. The medium to high temperature data here predict bright prospects for geothermal power and heat generation depending on formation permeability and other hydrodynamic parameters.

\section{Acknowledgement}

We appreciate the critical comments, advices and help of David Bruhn and István Almási.

\section{References}

Albu, I., Pápa, A., 1992. Application of high-resolution seismics in studying reservoir characteristics of hydrocarbon deposits in Hungary. Geophysics 8, 1068-1088.

Almási, I., 2001. Petroleum hydrogeology of the great hungarian plain, eastern pannonian basin, Hungary. PhD Thesis. University of Alberta, Canada, pp. 312.

Bérczi, I., 1988. Preliminary sedimentological investigation of a Neogene depression int he Great Hungarian Plain. In: Royden, L.H., Horváth, F. (Eds.), The Pannonian Basin; 
a Study in Basin Evolution. American Association of Petroleum Geologists Memoir, pp. 107-116.

Bada, G., Horváth, F., 1998. A Pannon-medence Jelenkori Tektonikája. Természet Világa, pp. 18-23 (II. különszám).

Barton, C.C., Larsen, E., 1985. Fractal geometry of two-dimensional fracture networks at Yucca Mountain, Southwestern Nevada. Stephanson, O. (Ed.), Proc. Int. Symp. on Fundamentals of Rock Joints 77-84.

Breede, K., Dzebisashvili, K., Liu, X., Falcone, G., 2013. A systematic review of enhanced (or engineered) geothermal systems: past, present and future. Geotherm. Energy 1 (4), 27.

Chapman, D.S., Keho, T., Bauer, M., Picard, M.D., 1984. Heat flow in the Uinta basin determined from bottom hole temperature (BHT) data. Geophysics 49, 453-466.

Csontos, L., Nagymarosi, A., 1999. Late Miocene inversion versus extension in the Pannonian Basin. Tübinger Geowiss. Arb. Ser. A 52, 132.

Cummings, R.G., Morris, G.E., 1979. Economic modeling of electricity production from hot dry rock geothermal reservoirs: methodology and analysis. EA-630, research project 1017 LASL (LA - 7888-HDR). OSTI Inf. Bridge.

Dövényi, P., Horváth, F., 1988. A review of temperature, thermal conductivity, and heat flow data for the Pannonian Basin. In: In: Royden, L.H., Horváth, F. (Eds.), The Pannonian Basin; a Study in Basin Evolution, vol. 45. American Association of Petroleum Geologists Memoir, pp. 195-233.

Dövényi, P., Horváth, F., Liebe, P., Gálfi, J., Erki, I., 1983. Geothermal conditions of Hungary. Geophys. Trans. 29, 84.

Dövényi, P., Homola, V., Horváth, F., Kohl, T., Rybach, L., 2005. European HDR/EGS resources: future potential development in Hungary. final report. GEOWATT AG 1-41 (May 26, 2005).

Diersch, H.-J., 2002. FEFLOW Finite-element Subsurface Flow and Transport Simulation System User's Manual/Reference Manual/White Papers, Release 5.0.

Erdélyi, M., 1976. Outlines of the hydodynamics and hydrochemistry of the Pannonian Basin. Acta Geol. Acad. Scientiarium Hungaricae 20, 287-309.

Gudmundsson, A., Berg, S.S., Lyslo, K.B., Skurtveit, E., 2001. Fracture networks and fluid transport in active fault zones. J. Struct. Geol. 23 (2-3), 343-353.

Gudmundsson, A., 2000. Fracture dimensions, displacements and fluid transport. J. Struct. Geol. 9, 1221-1231.

Haas, J., Budai, T., Csontos, L., Fodor, L., Konrád, G.Y., 2010. Magyarország Pre-kainozoos földtani térképe, 1: 500 000. Földtani Intézet kiadványa, Budapest.

Horváth, F., Musitz, B., Balázs, A., Végh, A., Uhrin, A., Nádor, A., Koroknai, B., Pap, N., Tóth, T., Wórum, G., 2015. Evolution of the Pannonian basin and its geothermal resources. Geothermics 53, 328-352.

Horváth, F., 1995. Phases of compression during the evolution of the Pannonian basinand its bearing on hydrocarbon exploration. Mar. Petrol. Geol. 12, 837-844.

IEA, 2011. Technology Roadmap -Geotherma Heat and Power. http://www.iea.org/ publications/freepublications/publication/Geothermal_roadmap.pdf.

Juhász, A.M., Tóth, T., Ramseyer, K., Matter, A., 2002. Connected fluid evolution in fractured crystalline basement and overlying sediments, Pannonian Basin, SE Hungary. Chem. Geol. 182, 91-120.

Lőrincz, K., 1996. Feszóltsügtür tértünet meghatörozösa szeizmikus szelvünyeken azonosátott tébbfözisí tektonizmus alapjön, a Szolnoki flis év nyugati peremün. (Determination of stress-field history on the basis of multiphase tectonism identified in seismic profiles in the Western part of the Szolnok flysh belt.). Magyar Geofizika 4 (37), 228-246.

La Pointe, P.R., 1988. A method to characterize fracture density and connectivity through fractal geometry. Int. J. Rock Mech. Mining Sci. Geomech. Abstr. 25, 421-429.

Mádl-Szőnyi, J., Tóth, J., 2009. A hydrogeological type section for the Duna-Tisza Interfluve. Hydrogeol. J. 4, 961-980.

Mádlné Szőnyi, J., Tóth, J., Simon, S.Z., Pogácsás, G.Y., 2005. Felszáni és felszánalatti vizek kapcsolatőnak eredménye a Duna-Tisza kózi Kelemen-szék és Kolon-tí esetében. Általános Földtani Szemle 30, 93-110.

Morrow, C., Lockner, D., Hickman, S., Rusanov, M., Röckel, T., 1994. Effects of lithology and depth on the permeability of core samples from the Kola and KTB drill holes. J. Geophys. Res. 99 (B4), 7263-7274.

Nelson, R.A., 2001. Geologic Analysis of Naturally Fractured Reservoirs, 2nd edition. Gulf Professional Publishing, Elsevier, pp. 332.

Oda, M., 1985. Permeability tensor for discontinuous rock masses. Geotechnique 35, 483-495.

Pap, S., Sőreg, V., Papné Hasznos, I., 1992. A Dévaványa-déli metamorf medencealjzati szerkezet szénhidrogénkutatási problémái -esettanulmány. Geophys.Trans 37, 211-228.

Pogácsás, Gy., Mattick, R.E., Tari, G., Várnai, P., 1994. Structural control on hydrocarbon accumulation in the pannonian basin, Hungary. Basin Anal. Petrol. Explor. 221-235.

Posgay, K., Bodoky, T., Hajnal, Z., Tóth, T., Fancsik, T., Hegedús, E., Kovács, A., 2006. Interpretation of subhorizontal crustal reflections by metamorphic and rheologic effects in the eastern part of the Pannonian Basin. Geophys. J. Int. 167 (1), 187-203.

Potter, R., Robinson, E., Smith, M., 1974. Method of extracting heat from dry geothermal reservoirs. US Patent No. 3, 786, 858, USA.Los Alamos, New Mexico.

Rybach, L., 2010. The future of geothermal energy and its challenges. Proc. World Geothermal Congress 2010 (CD ROM) Nusa Dua/Bali, Indonesia.

Schubert, F.M., Tóth, M., 2003. Successive, isothermal hydrocarbon migration events recorded by fluid inclusions in fracture-filling quartz in the Szeghalom Dome (Pannonian Basin, SE Hungary). Acta Mineral. Petrographica 44, 9-17.

Schubert, F., Diamond, L.W., Tóth, M.T., 2007. Fluid inclusion evidence of petroleum migration through a buried metamorphic dome in the Pannonian Basin, Hungary. Chem. Geol. 244 (3-4), 357-381.

Somfai, A., 1970. Examination of overpressured reservoirs in the Great Hungarian Plain: a classification of the causes of overpressure. Acta Mineral. - Petrographica Szeged XIX, 173-194.

Spencer, C.W., Szalay, A., Tatár, E., 1994. Abnormal pressure and hydrocarbon migration in the Békés Basin. In: Teleki, P.G., Mattick, R.E., Kókai, J. (Eds.), Basin Analysis in Petroleum Exploration; A Case Study from the Békés Basin. Kluwer Academic Publishers, Hungary, pp. 201-219 printed in the Netherlands.

Stevanovic, Z., Dulić, I., Dunčić, M., 2015. Some experiences in tapping deep thermal waters of the Triassic karstic aquifer in the Pannonian Basin of Serbia. Central Eur. Geol. 58 (1-2), 50-61.

Szalay, A., 1982. A túlnyomás okai és a paleopórusnyomás becslése (Causes of overpressures and estimation of paleo-pore pressures). Kóolaj ás Fóldgúz 115, 41-46.

Szalay, A., 1983. A nyomásgátak szerepe a szénhidrogén-migrációs folyamatokban (The role of pressure barriers in hydrocarbon migration processes). Kóolaj ás Földgáz 16, 363-371 (in Hungarian).

Szanyi, J., Kovács, B., 2010. Utilization of geothermal systems in South-East Hungary. Geothermics 39, 357-364.

Tóth, J., Almási, I., 2001. Interpretation of abserved fluid potential patterns in a deep sedimentary basin under tectonic compression: hungarian Great Plain, Pannonian Basin. Geofluids 1, 11-36.

Tóth, T., Schubert, F., 2000. Neogene exhumation of the variscan szeghalom dome, pannonian basin, E. Hungary. J. Geol. 35 (3-4), 265-284.

Tóth, M.T., Vass, I., 2011. Relationship between the geometric parameters of rock fractures, the size of percolation clusters and REV. J. Math. Geosci. 43, 75-97.

Tóth, T., Kedves, M., Schubert, F., 2003. Az Alfóld metamorf aljzatönak exhumöciája a Szeghalom-dám területén: palinolágiai bizonyítékok. Fóldtani Kózlóny 133 (4), $547-562$.

Tóth, M., Szúcs, T., Schubert, É., Hollós, F., 2004. Conceptual fracture network model of the crystalline basement of the Szeghalom Dome (Pannonian Basin, SE Hungary). Acta Geol. Hungarica 47 (1), 19-34.

Tóth, J., 2015. Geothermal phenomena in the context of gravity-driven basinal flow of groundwater. Central Eur. Geol. 58 (1-2), 1-27.

Tari, G., Horváth, F., Rumpler, J., 1992. Styles of extension in the Pannonian Basin. Tectonophysics 208, 203-219.

Tari, G., Dövényi, P., Dunkl, I., Horváth, F., Lenkey, L., Stefanescu, M., Szafián, P., Tóth, T., 2017. In: In: Durand, B., Jolivet, L., Horváth, F., Séranne, M. (Eds.), The Mediterranean Basins: Tertiary Extension Within the Alpine Orogen 156. Geological Society, London, pp. 215-250 (Special Publications).

Tari, G., 1994. Alpine tectonics of the Pannonian basin. PhD Thesis. Rice University, Houston, Texas, pp. 501.

Tester, J.W., Anderson, B.J., Batchelor, A.S., Blackwell, D.D., DiPippo, R., Drake, E.M., Garnish, J., Livesay, B., Moore, M.C., Nichols, K., Petty, S., Toksöz, M.N., Veatch Jr, R.W., 2006. The Future of Geothermal Energy - Impact of Enhanced Geothermal Systems on the United States in the 21 St Century 4-14. US Department of Energy, Washington, D.C, pp. 4-18.

Tsuchiya, N., Nakatsuka, K., 1995. A two-dimensional mono-fractal approach to natural fracture networks in rock. Geotherm. Sci. Technol. 6, 63-82.

Van Balen, R., Cloetingh, S., 1994. Tectonic control of the sedimentary record and stressinduced fluid flow: constraints from basin modelling. Geol. Soc. London 78, 9-26 (Special Publications).

Varsányi, I.ó., Kovács, L., 2009. Origin, chemical and isotopic evolution of formation water in geopressured zones in the Pannonian Basin, Hungary. Chem. Geol. 264, 187-196.

Vass, I., M, Tóth, T., Szanyi, J., Kovács, B., 2009. Az aljzati kristályos hátak szerepe az Alföld fluidum áramlási és hőtranszport folyamataiban. In: Tóth Tivadar, M. (Ed.), Magmás és Metamorf képződmények a Tiszai Egységben. Geolitera SZTE Földrajzi és Földtani Tanszékcsoport, Szeged, pp. 325-339.

Vass, I., 2013. Aljzati fluidum-tárolók komplex repedéshálózat vizsgálati módszeren alapuló hidrodinamikai és hőtranszport modellezése. PhD Thesis. University of Szeged, Hungary, pp. 134.

Vermilye, J.M., Scholz, C.H., 1995. Relation between vein length and aperture. J. Struct. Geol. 3, 423-434.

Witherspoon, P.A., Wang, J.S.Y., Iwai, K., 1980. Validity of cubic law for fluid flow in deformable rock fracture. Water Resour. Res. 16 (6), 1016-1024. 